\title{
STRENGTHENING STUDENTS' HEALTH IN THE PROCESS OF SPORTS AND HEALTH TOURISM ENGAGEMENT
}

D0I: 10.36740/WLek202106135

\author{
Zoia V. Syrovatko', Viktoriia M. Yefremenko' , Larysa V. Anikeienko', Viktor P. Bilokon', Serhii M. Korol', \\ Viktor G. Riabchenko ${ }^{3}$, Vitalii M. Koshel ${ }^{4}$ \\ 'NATIONAL TECHNICAL UNIVERSITY OF UKRAINE"IGOR SIKORSKY KYIV POLYTECHNIC UNIVERSITY", KYIV, UKRAINE \\ 2SUMY STATE UNIVERSITY, SUMY, UKRAINE \\ ${ }^{3}$ ACADEMY OF THE STATE PENITENTIARY SERVICE, CHERNIHIV, UKRAINE \\ ${ }^{4}$ T.H. SHEVCHENKO NATIONAL UNIVERSITY"CHERNIHIV COLEHIUM", CHERNIHIV, UKRAINE
}

\begin{abstract}
The aim: Is to investigate the level and dynamics of students' physical health in the process of sports and health tourism engagement.

Materials and methods: The research involved the students (men) of Sumy State University $(n=60)$. The research was conducted in 2018-2020. The comparative analysis of indicators of physical development, functional status and health of the students who were engaged in sports and health tourism (sports section of the Department of Physical Education, $n=30$ ) in the process of their physical education, and the students who attended traditional physical education classes (main section, $n=30$ ) was carried out. The level of the students' health was assessed according to the methods by H. L. Apanasenko and V. P. Voitenko.

Results: It was found that most indicators of physical development, functional status and state of health are significantly better at the end of the research in the students who were engaged in sports and health tourism during their education than in the students who were engaged in traditional physical education classes. The largest increases are in the indicators of body weight, circumferential size of the chest and the waist, heart rate, vital, strength indices, Robinson's index, duration of heart rate recovery after standard exercise, duration of breath-holding at inspiration and expiration, level of physical health.

Conclusions: The high level of physical development, functional status and the state of students' health formed in the process of sports and health tourism will ensure the effectiveness of their learning in higher educational institutions owing to improving their mental and physical performance, as well as help to improve indicators of their lifesustaining and future professional activities.
\end{abstract}

KEY WORDS: health, students, physical education, sports and health tourism

Wiad Lek. 2021;74(6):1478-1484

\section{INTRODUCTION}

One of the main tasks of the departments of physical education of higher educational institutions of Ukraine is to strengthen and maintain the students' health during their education, form physical culture and health competencies, develop interest and positive motivation for physical education during their study and for independent exercise and various types of sports and health activities in future $[1,2$, 3]. Health is a set of physical, spiritual, social qualities of human beings, which is the basis for their longevity and a necessary condition for their creative plans implementation, a condition of high efficiency, creating a strong family, birth and upbringing children, basis of good mood, well-being, cheerfulness, self confidence, etc. [4, 5].

According to the scientists $[6,7]$, physical health is a natural state of the body resulting from the normal functioning of all its organs and systems; it is perfection of self-regulation in the organism, harmony of physiological processes, maximum adaptation; it is a state of growth and development of organs and systems of the organism which basis is composed by the morphological and functional reserves providing adaptive reactions. Physical health is determined by such factors as individual features of the anatomical structure of the body, physiological functions of the body in different conditions of rest, movement, environment, genetic heritage, levels of physical development of organs and systems of the body [8,9]. Physical health integrates the human body as a biological system i. e. organs and life support systems, their functions and health, physical activities and biochemical processes, body hygiene, motor performance, healthy nutrition, genetic and reproductive health, disease prevention. The most important indicators of human physical health are physical development, physical performance, physical fitness, and physical activity $[10,11,12]$.

There are a number of studies, including the one by the World Health Organization, which state that human health depends on $20 \%$ of heredity, $10 \%$ on the level of development of medicine, $20 \%$ on the environment and $50 \%$ on lifestyle [13]. Other sources state that human 
health depends on genetics by $15-20 \%$, on the quality of the health care system in the country by $10-15 \%$, on the degree of environmental pollution by $20-25 \%$ and on social conditions and lifestyle by $50-55 \%[14,15]$.

According to many scientists [16], there has been a deterioration in the state of health and level of physical fitness of both students and pupils in Ukraine recently. Thus, according to the Ministry of Health of Ukraine, about $90 \%$ of students in the country face health problems. According to the research results [17], the state of health of student youth is deteriorating every year with the increase in the number of students with chronic diseases of various origins. The most common are diseases of the cardiovascular system, including atherosclerosis, coronary heart disease, hypertension, myocardial infarction, cerebrovascular disorders [18]. The structure of students morbidity during one calendar year was dominated by colds (39.2\% in males, $65.2 \%$ in females), respiratory system $11.0 \%$ and $18.9 \%$ respectively, cardiovascular $-5.5 \%$ and $12.7 \%$, musculoskeletal system $-10.5 \%$ and $8.1 \%$, nervous system $3.4 \%$ and $7.4 \%$. In addition, there were diseases of the visual organs, digestive organs, urinary tract, etc. [19]. According to the results of assessing the physical fitness of students of various institutions of higher education in Ukraine, the scientists [20] found that more than $65 \%$ of first year students cannot perform physical fitness tests with the "satisfactory" grade without prior training. They have significant physical defects, diseases; from 15 to $30 \%$ of the first-year students, according to various scientists [21], are classified as a special medical group, and from 1 to $3 \%$ are generally exempt from physical activities, have chronic diseases and permanent disabilities. This is primarily due to the low level of the state of health of school graduates, the lifestyle of modern youth, the devaluation of the social prestige of a healthy lifestyle; insufficient efficiency of organization and conduct of traditional forms of physical education, and, as a consequence, low level of motivation for traditional physical education classes, insufficient health and training orientation of physical education $[22,23,24]$. The researches stipulate for the search and implementation of modern sports and health technologies that would increase students' interest in exercise and sports, strengthen their health, improve their physical and mental performance and, further, increase the efficiency of their future professional activities. Sports and health tourism can be one of the modern means of students' health strengthening. Tourism has a large number of definitions $[25,26,27]$, one of which is defined as a component of recreation, its active form, for relaxation, entertainment, health improvement, knowledge of nature, culture and life of the population, other areas, etc. $[28,29]$. Another definition of tourism is a form of education of physical and mental abilities of a human being through the increase of knowledge of country studies and home science, history, geography, culturology provided in the process of travel; through the formation of a system of physical activities, general physical training, knowledge, skills and abilities to survive in natural conditions, overcome natural obstacles, etc. [30]. Tourism is a multifunctional phenomenon. The essence of tourism as a mobile form of recreation is the knowledge of natural, socio-cultural and economic features of the territory in the process of travel [31]. The main functions of tourism should include recreational (relaxation, recovery, rehabilitation), remedial, social, cultural, environmental, economic, educational, instructional, sports, religious and other ones [32]. There are many approaches to the classification of types of tourism; tourism depending on the purpose of travel is divided into sports, cognitive (excursion), amateur, recreational, health-related, rehabilitation, professionally-applied, combined and many other types. Introduction of tourism to the educational process on physical education as one of the modern types of sport and health technologies and a means of increasing students' motor activities, improving their physical fitness is the basis of scientific research of many scientists [33, 34]. The works by the scientists [35] reveal that tourism activities have a significant physiological effect on students, and walks after learning activities, weekend hikes and multi-day country walks affect the activation of mental processes, rapid recovery and increase of mental capacity of students. Sports and health tourism combines various physical exercises, cognitive and educational elements, elements of hardening and adaptation to unusual conditions, has an emotional colouring, increases the body's resistance to negative environmental factors, helps to maintain high performance [27,30]. At the same time, the issue of the impact of sports and health tourism on strengthening the students' health in the process of studying in higher educational institutions requires further research.

\section{THE AIM}

The aim of this study is to investigate the level and dynamics of students' physical health in the process of sports and health tourism engagement.

\section{MATERIALS AND METHODS}

\section{PARTICIPANTS}

The research involved the students (men) of Sumy State University $(n=60)$. The research was conducted in 20182020 when the students were in the 1st and 2nd years of their education. The comparative analysis of indicators of physical development, functional status and health of the students who were engaged in sports and health tourism (sports section of the Department of Physical Education, experimental group $(E G), n=30$ ) in the process of their physical education, and the students who attended traditional physical education classes (main section, control group (CG), $n=30$ ) was carried out. All studied indicators of the EG and the CG students were significantly the same $(p>0.05)$ at the beginning of the research. The number of physical education academic hours per week for the students of the EG and the CG was the same.

\section{METHODS}

We used a group of scientific methods to achieve the purpose of the research such as theoretical analysis and generalization of scientific and educational literature, which allowed to 
Table I. Dynamics of indicators of physical development of the students of the $E G$ and the $C G$ during their learning process (Mean $\pm S D$ )

\begin{tabular}{|c|c|c|c|c|}
\hline \multirow{2}{*}{$\begin{array}{l}\text { Indicators of physical } \\
\text { development }\end{array}$} & \multirow{2}{*}{$\begin{array}{l}\text { Stages of the } \\
\text { research }\end{array}$} & \multicolumn{2}{|c|}{ Study groups of students } & \multirow{2}{*}{$\begin{array}{l}\text { Certainty of the } \\
\text { difference }\end{array}$} \\
\hline & & EG $(n=30)$ & CG $(n=30)$ & \\
\hline \multirow{2}{*}{ Body weight, kg } & Beginning & $71.9 \pm 1.02$ & $72.0 \pm 1.04$ & $t=0.05 ; p>0.05$ \\
\hline & End & $72.3 \pm 0.98$ & $75.2 \pm 1.06$ & $\mathrm{t}=2.02 ; \mathrm{p}<0.05$ \\
\hline \multirow{2}{*}{ Body length, $\mathrm{cm}$} & Beginning & $175.4 \pm 1.01$ & $175.3 \pm 0.89$ & $t=0.07 ; p>0.05$ \\
\hline & End & $175.6 \pm 0.99$ & $175.5 \pm 0.86$ & $t=0.08 ; p>0.05$ \\
\hline \multirow{2}{*}{ Body mass index, $\mathrm{kg} / \mathrm{m}^{2}$} & Beginning & $23.37 \pm 0.48$ & $23.42 \pm 0.45$ & $t=0.08 ; p>0.05$ \\
\hline & End & $23.45 \pm 0.46$ & $24.41 \pm 0.50$ & $t=1.41 ; p>0.05$ \\
\hline \multirow{2}{*}{$\begin{array}{l}\text { Circumferential size of the chest, } \\
\qquad \mathrm{cm}\end{array}$} & Beginning & $91.9 \pm 0.72$ & $92.0 \pm 0,74$ & $t=0.10 ; p>0.05$ \\
\hline & End & $95.5 \pm 0.66$ & $93.4 \pm 0.71$ & $t=2.17 ; p<0.05$ \\
\hline \multirow{2}{*}{$\begin{array}{l}\text { circumferential size of the waist, } \\
\qquad \mathrm{cm}\end{array}$} & Beginning & $77.3 \pm 0.88$ & $77.4 \pm 0,84$ & $t=0.08 ; p>0.05$ \\
\hline & End & $77.4 \pm 0.85$ & $79.8 \pm 0.82$ & $t=2.03 ; p<0.05$ \\
\hline \multirow{2}{*}{ Wrist dynamometry, kg } & Beginning & $38.2 \pm 0.97$ & $38.4 \pm 0.94$ & $t=0.15 ; p>0.05$ \\
\hline & End & $42.8 \pm 0.92$ & $40.5 \pm 0.91$ & $t=1.78 ; p>0.05$ \\
\hline \multirow{2}{*}{ Strength index, \% } & Beginning & $53.1 \pm 1.21$ & $53.3 \pm 1.19$ & $t=0.12 ; p>0.05$ \\
\hline & End & $59.2 \pm 1.18$ & $53.9 \pm 1.20$ & $t=3.15 ; p<0.01$ \\
\hline
\end{tabular}

clarify the current state of the problem under study, to systematize and summarize information on the research topic; empirical: pedagogical observation, questionnaires, medical and biological methods for studying the impact of sports and health tourism on physical development, functional status and health of the students during their education; methods of mathematical statistics, in particular the selective method for qualitative and quantitative processing of digital data, identification of the validity of the research results. Physical development of the students was assessed by indicators of body length, body weight, circumferential size of the chest and the waist, wrist dynamometry, body mass index, and strength index. The functional status of the main systems of the students' body was assessed by indicators of heart rate at rest, systolic and diastolic blood pressure, vital capacity of the lungs, duration of breath-holding at inspiration (using timed inspiratory capacity); duration of breath-holding at expiration (timed expiratory capacity), Robinson's index, vital index, heart rate recovery time to baseline after standard exercise [36]. The level of the students' health was assessed according to the method by H. L. Apanasenko, which provided for the calculation of body weight, vital, strength, Robinson's indices and heart rate recovery time to baseline after standard exercise [37]. In order to make a self-assessment of students' own health, we used the method by V. P. Voitenko, the essence of which is to survey the students on a questionnaire containing 27 questions, with awarded points according to the answers provided by the students. The total score determined the quantitative self-assessment of health [38].

\section{STATISTICAL ANALYSIS}

During the research the authenticity of difference between the indicators of students of EG and CG by means of Student's criterion was determined. The dynamics of indicators in each of groups was also estimated. The significance for all statistical tests was set at $\mathrm{p}<0.05$. All statistical analyses were performed with the SPSS software, version 21, adapted to medical and biological researches.

\section{ETHICAL APPROVAL}

The research related to human has been complied with all the relevant national regulations and institutional policies. The research was performed according to the requirements of the Regulations on Academic Honesty of the Sumy State University, which were developed on the basis of Ukrainian and world experience of ethical rulemaking. According to its provisions, the members of the scientific community are guided by the rules of ethical conduct and professional communication; respect the principles, values, norms, rules, and conditions of academic honesty, follow examination procedure, and evaluation criteria for academic plagiarism. The research has also followed the tenets of the World Medical Association (WMA) Declaration of Helsinki - ethical principles for medical research involving human subjects. Informed consent has been obtained from all students included in this study.

\section{RESULTS}

The results of the comparative analysis of indicators of physical development of the students who were engaged in sports and health tourism (EG) in the process of their education, and the students who attended traditional physical education classes (CG) are presented in Table I. It was found that no significant difference between the EG and the CG were detected ( $\mathrm{p}>$ 0.05 ) for all studied indicators of physical development at the beginning of the research. Most indicators of physical development were better in the students of the CG $(p<0.05-0.01)$ 
Table II. Dynamics of indicators of functional status of the students of the $E G$ and the $(G$ during their learning process (Mean $\pm S D$ )

\begin{tabular}{|c|c|c|c|c|}
\hline \multirow{2}{*}{ Indicators of functional status } & \multirow{2}{*}{$\begin{array}{l}\text { Stages of the } \\
\text { research }\end{array}$} & \multicolumn{2}{|c|}{ Study groups of students } & \multirow{2}{*}{$\begin{array}{l}\text { Certainty of the } \\
\text { difference }\end{array}$} \\
\hline & & EG $(n=30)$ & EG $(n=30)$ & \\
\hline \multirow{2}{*}{ Heart rate at rest, beats / min } & Beginning & $70.4 \pm 0.84$ & $70.6 \pm 0.79$ & $t=0.17 ; p>0.05$ \\
\hline & End & $68.7 \pm 0.75$ & $70.8 \pm 0.71$ & $t=2.03 ; p<0.05$ \\
\hline \multirow{2}{*}{ Systolic blood pressure, $\mathrm{mmHg}$} & Beginning & $120.2 \pm 0.93$ & $120.5 \pm 0.88$ & $t=0.88 ; p>0.05$ \\
\hline & End & $120.1 \pm 0.92$ & $120.6 \pm 0.86$ & $t=0.40 ; p>0.05$ \\
\hline \multirow{2}{*}{ Diastolic blood pressure, $\mathrm{mmHg}$} & Beginning & $70.5 \pm 0.87$ & $70.8 \pm 0.82$ & $t=0.25 ; p>0.05$ \\
\hline & End & $70.5 \pm 0.85$ & $70.8 \pm 0.83$ & $t=0.25 ; p>0.05$ \\
\hline \multirow{2}{*}{ Vital capacity of the lungs, $\mathrm{ml}$} & Beginning & $4054.1 \pm 95.14$ & $4061.2 \pm 94.57$ & $t=0.05 ; p>0.05$ \\
\hline & End & $4377.4 \pm 94.27$ & $4127.7 \pm 95.18$ & $t=2.01 ; p<0.05$ \\
\hline \multirow{2}{*}{$\begin{array}{l}\text { Duration of breath-holding at } \\
\text { inspiration, } s\end{array}$} & Beginning & $61.7 \pm 1.12$ & $61.3 \pm 1.08$ & $t=0.26 ; p>0.05$ \\
\hline & End & $69.8 \pm 1.05$ & $66.5 \pm 1.11$ & $t=2.16 ; p<0.05$ \\
\hline \multirow{2}{*}{$\begin{array}{c}\text { Duration of breath-holding at } \\
\text { expiration, s }\end{array}$} & Beginning & $41.8 \pm 0.77$ & $41.5 \pm 0.74$ & $t=0.28 ; p>0.05$ \\
\hline & End & $44.5 \pm 0.72$ & $42.3 \pm 0.71$ & $t=2.18 ; p<0.05$ \\
\hline \multirow{2}{*}{ Vital index, $\mathrm{ml} / \mathrm{kg}$} & Beginning & $56.4 \pm 0.96$ & $56.4 \pm 0.94$ & $t=0.01 ; p>0.05$ \\
\hline & End & $60.5 \pm 0.93$ & $54.8 \pm 0.92$ & $t=4.36 ; p<0.001$ \\
\hline \multirow{2}{*}{ Robinson's index, c.u. } & Beginning & $84.6 \pm 0.91$ & $85.1 \pm 0.87$ & $t=0.40 ; p>0.05$ \\
\hline & End & $82.5 \pm 0.88$ & $85.4 \pm 0.89$ & $\mathrm{t}=2.32 ; \mathrm{p}<0.05$ \\
\hline \multirow{2}{*}{ Heart rate recovery time, s } & Beginning & $130.8 \pm 3.11$ & $131.2 \pm 3.04$ & $t=0.09 ; p>0.05$ \\
\hline & End & $111.6 \pm 2.58$ & $119.4 \pm 2.64$ & $t=2.11 ; p<0.05$ \\
\hline
\end{tabular}

at the end of the research. The most pronounced changes were revealed in the body weight, circumferential size of the chest and the waist as well as strength index.

Thus, at the end of the research, the body weight in the EG students was significantly lower than in the CG students by $2.9 \mathrm{~kg}(\mathrm{p}<0.05)$, and the body-weight index was better by $0.96 \mathrm{~kg} / \mathrm{m}^{2}(\mathrm{p}<0.05)$. At the same time, during the research period, the body weight of the students who were engaged in tourism did not significantly deteriorate $(\mathrm{p}>$ $0.05)$, and it significantly deteriorated by $3.2 \mathrm{~kg}(\mathrm{p}<0.05)$ in the students who attended traditional physical education classes. This indicates the effectiveness of sports and health tourism to maintain the body weight of the students in a normal state during the process of their education. It was also found that the circumferential size of the chest in the EG students is significantly better than in the CG by 2.1 $\mathrm{cm}$, and the waist - by $2.4 \mathrm{~cm}(\mathrm{p}<0.05)$ at the end of the research. There was also an improvement in the strength indicators of the EG students i. e. the strength index of the EG students was significantly better than that in the CG by $5.3 \%$ at the end of the research. This indicates that much better physical development of the students is taking place in the process of sports and health tourism than in the process of classes according to the traditional method of conducting physical education classes.

The comparative analysis of the functional status indicators of the EG and the CG students in the process of their education showed that significantly $(\mathrm{p}<0.05-0.001)$ better average values in the EG students at the end of the research were revealed in the indicators of heart rate at rest, vital lung capacity, duration of breath-holding at inspiration and expiration, vital index, Robinson's index, and heart rate recovery time after standard exercise (Table II). The difference between the indicators of the EG and the CG at the end of the research is 2.1 beats / $\mathrm{min}$ in the indicators of heart rate, 249.7 $\mathrm{ml}$ in vital lung capacity, $3.3 \mathrm{~s}$ in duration of breath-holding at inspiration, $2.2 \mathrm{~s}$ in duration of breath-holding at expiration, $5.7 \mathrm{ml} / \mathrm{kg}$ in vital index, $2.9 \mathrm{c}$. u. in Robinson's index, $7.8 \mathrm{~s}$ in heart rate recovery time. It is important to note that some indicators significantly improved (vital lung capacity at $\mathrm{p}<0.05$; duration of breath-holding at inspiration and expiration at $p<0.05$; vital index at $p<0.01$; duration of heart rate recovery at $p<0.001$ ) in the students of the EG during the period of their education, and they did not significantly ( $p>0.05$ ) change in the CG. The analysis showed that sports and health tourism classes are more effective than traditional physical education classes in relation to the improvement of the functionality of the main systems of the student's body, including the cardiovascular system and respiratory system.

The comparative analysis of the level of health of the EG and the CG students showed that according to the method by H. L. Apanasenko and according to the method by V. P. Voitenko the level of the students' health who attended sports and health tourism classes was significantly ( $\mathrm{p}<$ 0.01 ) better at the end of the research, than that of the students' who attended traditional physical education classes (Table III). The difference between the studied indicators at the end of the research is 2.12 points according to the method by H. L. Apanasenko and 3.26 points according to the method by V. P. Voitenko.

The level of health in both groups improved during the research period, but a larger increase was found in the 
Table III. Dynamics of indicators of health of the students of the EG and the CG during their learning process (Mean \pm SD), points

\begin{tabular}{|c|c|c|c|c|}
\hline \multirow{2}{*}{ Indicators of functional status } & \multirow{2}{*}{$\begin{array}{l}\text { Stages of the } \\
\text { research }\end{array}$} & \multicolumn{2}{|c|}{ Study groups of students } & \multirow{2}{*}{$\begin{array}{l}\text { Certainty of the } \\
\text { difference }\end{array}$} \\
\hline & & EG $(n=30)$ & EG $(n=30)$ & \\
\hline \multirow{2}{*}{ Method by H. L. Apanasenko } & Beginning & $2.89 \pm 0.52$ & $2.93 \pm 0.46$ & $t=0.06 ; p>0.05$ \\
\hline & End & $7.14 \pm 0.45$ & $5.02 \pm 0.41$ & $t=3.48 ; p<0.01$ \\
\hline \multirow{2}{*}{ Method by V. P. Voitenko } & Beginning & $14.02 \pm 0.81$ & $13.97 \pm 0.74$ & $t=0.05 ; p>0.05$ \\
\hline & End & $9.17 \pm 0.72$ & $12.43 \pm 0.65$ & $t=3.36 ; p<0.01$ \\
\hline
\end{tabular}

group of the students engaged in sports and health tourism. Herewith, the level of health in the EG is assessed as average and as below average in the CG at the end of the research, which once again confirms the effectiveness of sports and health tourism to strengthen the students' health in the process of their education.

\section{DISCUSSION}

As stated in the Law of Ukraine "On Physical Culture and Sports" (2020), physical culture in the education sphere aims at ensuring the physical health development of the school and university students, a comprehensive approach to the formation of mental and physical abilities of the individual, improving physical and psychological preparation for active life, professional activity on the principles of individual approach, the priority of health orientation, the widespread use of various means and forms of physical education and mass sports, the continuity of this process throughout life.

The scientists $[2,7,39]$ distinguish several types of health: somatic, physical, mental, and aesthetic. Somatic health is the state of the human body at a given point in time. The basis of somatic health is the genetic program of individual human development. This development program is directly related to the needs of nutrition, physical activities, knowledge of the environment, and so on. Aesthetic health is a set of characteristics of the motivational and informational basis of human life. The basis of aesthetic health is a system of values, attitudes, motives for individual behaviour in the social environment. Aesthetic health is associated with the universal concepts of goodness, love, beauty and it determines the spirituality of human being to some extent. Physical health, as a direction of scientific knowledge of the phenomenon of "health", determines sense of well-being, cheerfulness, availability of energy, efficiency, absence of symptoms of diseases. Physical health is determined by a number of factors $[40,41]$ : individual features of the anatomical structure of the body, physiological functions of the body in different conditions of rest and movement, environment, genetic component, levels of physical development of organs and systems. The most important indicators of physical health are physical development, physical performance, physical fitness, and physical activity.

The factors that shape health according to the scientists $[16,40,42,43]$ include absence of bad habits, physical activity, sensible nutrition, ability to handle stress, desire for spiritual and aesthetic improvement, realization of creative potential, medical control, control over the environment, health procedures, adherence to personal and public hygiene rules, control of sexual and interpersonal relationships, mastering the techniques of psychoregulation. Features of everyday life also characterize the way of life, namely educational and work activities, everyday life, forms of leisure activities, satisfaction of material and spiritual values, participation in public life, norms and rules of conduct, etc. [18].

According to the researches by many scientists $[6,14]$, an effective system of health formation involves the simultaneous implementation of a number of focus areas, namely: ensuring real health by increasing the level of adaptive capacity of the body, the ability to protect (or compensate) from negative influences or to make the most of the positive impact of the factor on health (prevention of negative and formation of positive effects); creating a favourable environment by reducing negative factors or creating conditions for maximum realization of the positive properties of the factor (direct focus on health factors); ensuring conscious control of one's own health by promoting the skills of a healthy lifestyle and valeological education; creating a system of active health monitoring, which provides for a regular and systematic longitudinal study of the psychological, physical and somatic components of health and active use of acquired information in the process of valeological education. Also, according to many scientists $[3,11]$, one of the main factors in shaping, strengthening and maintaining the students' health is their active participation in the educational process of physical education and sports activities, both during their education and within extracurricular academic hours. The scientists from around the world conducted a large number of scientific studies to identify the effectiveness of various types of exercise and sports, the use of modern fitness technology and other types of health and fitness as well as sports activities to improve the health of young people. Our research concerning the impact of sports and health tourism on the level and dynamics of physical health of the students significantly expands and confirms the findings of many scientists working in this area. Sports and health tourism is closely related to other sports such as orienteering, rock-climbing, water slalom, mountaineering, ski sport, track and field events, etc. [26, 30]. This connection is multifaceted, and is manifested in the fact that sports tourism actively uses techniques of other sports, which contributes to the significant physical development of the students who are engaged in it [27, 32]. An important feature and advantage 
of sports tourism is that, unlike most other sports, it requires almost no material costs, as it is carried out in the existing environment and does not require significant investment for the preparation and conduct of tourism and sports activities as well as erection of special structures for their implementation; logistical and organizational support of these activities is carried out by the forces and means of the tourists themselves [34, 35]. In addition, sports and health tourism can be effectively implemented in the physical education of schoolchildren - future university students.

\section{CONCLUSIONS}

The comparative analysis of the indicators of physical development, functional status and level of health of the students engaged in sports and health tourism (EG) and the students engaged in traditional physical education (CG), shows that average values according to the most studied indicators are significantly $(\mathrm{p}<0.05-0.001)$ better in the EG students than in the CG students at the end of the research. The greatest positive impact from sports and health tourism was incurred by the indicators of the EG students such as body weight, circumferential size of the chest and the waist, heart rate, vital, strength indices, Robinson's index, duration of heart rate recovery and duration of breath-holding at inspiration and expiration. In addition, it was found that sports and health tourism effectively affects the students' health strengthening - and according to the method by H. L. Apanasenko and according to the method by V. P. Voitenko, the level of the students' health who attended sports and health tourism classes was significantly $(p<0.01)$ better at the end of the research than that of the students' who attended traditional physical education classes. The difference between the studied indicators at the end of the research is 2.12 points according to the method by H. L. Apanasenko and 3.26 points according to the method by V. P. Voitenko. The high level of the studied indicators of the students will ensure the effectiveness of their learning in higher educational institutions owing to improving their mental and physical performance, as well as help to improve the psycho-emotional state of the students and other indicators of their life-sustaining and future professional activities.

Prospects for further research are to study the impact of sports and health tourism on the state of health and mental performance of female students.

\section{REFERENCES}

1. Griban G., Lyakhova N., Tymoshenko 0. Current state of students' health and its improvement in the process of physical education. Wiad. Lek. 2020; 73(7): 1438-1447. doi: 10.36740/WLek202007124.

2. Prontenko K., Bloshchynskyi I., Griban, G. et al. Formation of readiness of future physical culture teachers for professional activity. Universal Journal of Educational Research. 2019; 7(9): 1860-1868. doi: 10.13189/ ujer.2019.070903.

3. Prysiazhniuk S., Tolubko V., Oleniev D. et al. The influence of physical activities on biological age parameters of the first-year female students from the special medical department. Journal of Physical Education and Sport. 2018; 18(2): 561-564. doi:10.7752/jpes.2018.02081.
4. Mozolev 0., Bloshchynsky I., Alieksieiev 0 . et al. Influence of modern fitness technologies on the state of health and development of motor abilities of 17-19-year-old female students. Journal of Physical Education and Sport. 2019; 19(3): 917-924. doi:10.7752/jpes.2019. s3132.

5. Griban G., Kobernyk 0., Terentieva N. et al. Formation of health and fitness competencies of students in the process of physical education. Sport Mont. 2020; 18(3): 73-78. doi: 10.26773/smj.201008.

6. Prontenko K., Griban G., Dovgan N. et al. Students' health and its interrelation with physical fitness level. Sport Mont. 2019; 17(3): 41-46. doi 10.26773/smj.191018.

7. Gruzieva T., Galiienko L., Pelo I. et al. Health and lifestyle of students' youth: status, problems and ways of solution. Wiad Lek. 2018; 71(9): 1753-1758.

8. Zhamardiy V., Shkola 0., Okhrimenko I. et al. Checking of the methodical system efficiency of fitness technologies application in students physical education. Wiad Lek. 2020; 73 (2): 332-341. doi: 10.36740/ WLek202002125.

9. Prontenko K., Griban G., Aloshyna A. et al. The physical development and functional state as the important components of the students' health. Wiad. Lek. 2019; 72(12a):2348-2353. doi: 10.36740/WLek201912115.

10. Mozolev 0., Khmara M., Shorobura I. et al. Comparative analysis of the effectiveness of Polish and Ukrainian basic training programs in physical education for 9-10-year-old pupils. Universal Journal of Educational Research. 2019; 7(11): 2345-2351. doi: 10.13189/ujer.2019.071112.

11. Griban G., Tymoshenko 0., Arefiev V. et al. (2020). The role of physical education in improving the health status of students of special medical groups. Wiad. Lek. 2020; 73 (3):534-540. doi: 10.36740/WLek202003125.

12. Tymoshenko 0., Arefiev V., Domina Zh. et al. Exercise machines in speed and coordination development among students playing basketball. International Journal of Human Movement and Sports Sciences. 2021; 9(2): 347-355. doi: $10.13189 /$ saj.2021.090224.

13. World Health Organization. Global recommendations on physical activity for health. 2015. http://www.who.int/dietphysicalactivity/ factsheet_recommendations.

14. Warburton D., Nicol C. W., Bredin S. S. D. Health benefits of physical activity: the evidence. Canadian Medical Association Journal. 2006; 174: 801-809.

15. Griban G., Yavorska T., Tkachenko P. et al. Motor activity as the basis of a healthy lifestyle of student youth. Wiad. Lek. 2020; 73(6): 1199-1206. doi: 10.36740/WLek202006123.

16. Bulych E.Gh., MuravovY.V.Zdorovje cheloveka: Byologhycheskaja osnova zhyznedejateljnosty y dvyghateljnaja aktyvnostj vee stymuljacyy [Human health: the biological basis of vital activity and motor activity in its stimulation]. Kyiv: Olympic Literature; 2002, 424 p. (In Russian).

17. Griban G., Prontenko K., Kostyuk Yu. et al. Formation of middle school pupil movements using basketball. Journal of Physical Education and Sport. 2018; 18 (1): 304-309. doi: 10.7752/jpes.2018.01041.

18. Paffenbarger R. S., Olsen E. Zdorovyiy obraz zhizni [Healthy lifestyle]. Kyiv: Olympic Literature; 1999, 320 p. (In Russian).

19. Mozolev 0., Bloshchynskyi I., Prontenko K. et al. Influence of fitness techniques integration on the development of physical qualities and morpho-functional state of adult females. Human Movement. 2021; 22(1): 57-65. https://doi.org/10.5114/hm.2021.98465.

20. Prontenko K., Griban G., Bloshchynskyil. et al. Improvement of students' morpho-functional development and health in the process of sportoriented physical education. Wiad Lek. 2020; 73(1): 161-168. doi: 10.36740/WLek202001131. 
21. Griban G., Myroshnychenko M., Tkachenko P. et al. Bad habits and their impact on students' health. Wiadomości Lekarskie, Wiad Lek. 2020; 73(11): 2386-2395. doi: 10.36740/WLek202011111.

22. Bloshchynskyi I., Griban G., Okhrimenko I. et al. Formation of psychophysical readiness of cadets for future professional activity. The Open Sports Sciences Journal. 2021; 14: 1-8. doi: 10.2174/1875399X02114010001.

23. Plisko V., Doroshenko T., Minenok A. et al. Informational indicators of functional capacities of the body for teaching cadets from higher military educational institutions power types of sports. Journal of Physical Education and Sport. 2018; 18 (2): 1050-1054. doi: 10.7752/ jpes.2018.s2156.

24. Griban G., Dzenzeliuk D., Dikhtiarenko Z. et al. Influence of sambo wrestling training on students' physical fitness. Sport Mont. 2021; 19(1): 89-95. doi: 10.26773/smj.210219.

25. BiernatE., Lubowiecki-VikukA. P. Correlations between individual factors and long-term nature of tourist trips amongst urban single people. Balt J Health Phys Activ. 2013;5(2). https://doi.org/10.2478/bjha-2013-0014.

26. Jaksic-Stojanovic A., Jankovic M., Seric N. Montenegro as high-quality sports tourism destination-trends and perspectives. Sport Mont. 2019; 17(1): 93-95. doi: 10.26773/smj.190218.

27. Fedotov Yu. N., Vostokov I. E. Sportivno-ozdorovitelnyiy turizm [Sports and health tourism]. Moskva: Sovetskiy sport, 2008; 464 p. (In Russian).

28. Tomik R., Gorska K., Staszkiewicz A., Polechonski, J. Motives for participation in active sport tourism - participants of holiday windsurfing camps. Balt J Health Phys Activ. 2014; 6(3). https://doi. org/10.2478/bjha-2014-0021.

29. Ndayisenga, J. The perception of international students on the facility and sport tourism event management. Sport Mont. 2019; 17(2):53-58. doi: 10.26773/smj.190609.

30. Mulik K. V. Sportivno-ozdorovchiy turizm v sistemi fizichnogo vihovannya shkolyariv i studentiv [Sports and health tourism in the system of physical education of schoolchildren and students]. Harklv: FOP Brovln A. V., 2015; 418 p. (In Ukrainian).

31. Ratkowski W., Ratkowska J. Sports events as a determinant of sport tourism. Balt J Health Phys Activ. 2018; 10: 86-94. https://doi. org/10.29359/BJHPA.10.1.09.

32. Cerić D., Więckowski M. Establishing transboundary tourist space in the Baltic Sea region. Balt J Health Phys Activ. 2020; 12: 149-157. https:// doi.org/10.29359/BJHPA.12.Spec.Iss1.16.

33. Cesario S. K. Implications of medical tourism. Nursing for women's health, 2018; 22(3): 269-273. https://doi.org/10.1016/j.nwh.2018.03.008.

34. Grinova T. I., Mulik K. V. Dinamika pokaznikiv fizichnih yakostey hloptsiv 10-13 rokiv pid vplivom zanyat riznimi vidami turizmu [Dynamics of indicators of physical qualities of boys 10-13 years old under the influence of various types of tourism]. Pedagogika, psihologiya ta mediko-biologichni problemi flzichnogo vihovannya ta sportu. 2013; 10: 16-21. doi: 10.6084/m9.figshare.775317. (In Ukrainian).

35. Schur Yu. V., Dmitruk 0. Yu. Sportivno-0zdorovchiy turizm [Sports and health tourism]. Kiyiv: Alterpres, 2003; 232 p.

36. Dubrovskiy V. I. Sportivnaya fiziologiya [Sports physiology]. Moskva, 2005; 462 p. (In Russian).

37. Apanasenko G., Dolzhenko L. Rivenj zdorov'ja i fiziologhichni rezervy orghanizmu. [The level of health and physiological reserves of the organism]. Teorija i metodyka fizychnogho vykhovannja i sportu. 2007; 1: 17-21. (In Ukrainian).

38. Voytenko V. P. Zdorove zdorovyih [Healthy health]. - Kyiv: Zdorov'ya; 1991, 248 p. (In Russian).
39. Griban G., Prontenko K., Zhamardiy V. et al. Professional stages of a physical education teacher as determined using fitness technologies. Journal of Physical Education and Sport. 2018; 18(2): 565-569. doi:10.7752/jpes.2018.02082.

40. Muntjan V. S. Analyz faktorov, opredeljajushhykh zdorovj'e cheloveka y okazyvajushhykh na negho vlyjanyja [Analysis of factors that determine human health and influence it]. Fyzycheskoe vospytanye studentov. 2010; 6: 44-47. (In Russian).

41. Prontenko K., Griban G., Prontenko V. et al. Health improvement of cadets from higher military educational institutions during kettlebell lifting activities. Journal of Physical Education and Sport. 2018; 18 (1): 298-303. doi: 10.7752/jpes.2018.01040.

42. Khoroshukha M., Griban G., Terentieva N. et al. Influence of different training activities on development of junior athletes' logical thinking. International Journal of Human Movement and Sports Sciences. 2021; 9(1): 62-70. doi: 10.13189/saj.2021.090109.

43. Griban G., Kuznietsova 0., Tkachenko P. et al. Formation of the students' volitional qualities in the process of physical education. International Journal of Human Movement and Sports Sciences. 2020; 8(6): 505-517. doi: 10.13189/saj.2020.080625.

This research was carried out according to the research work of Sumy State University for 2020-2022 on the theme of "Values of socio-gender and legal bases of forms of political counteraction to discrimination and violence in society" (state registration number 0119U000205).

\section{ORCID and contributionship:}

Zoia V. Syrovatko: 0000-0002-5752-9445

Viktoriia M. Yefremenko: 0000-0002-7723-5161

Larysa V. Anikeienko: 0000-0002-1781-3353 ${ }^{C, D}$

Viktor P. Bilokon: 0000-0003-2763-5965 ${ }^{B, D}$

Serhii M. Korol: 0000-0001-5949-4699A

Viktor G. Riabchenko: 0000-0002-5630-9459E

Vitalii M. Koshel: 0000-0001-7547-28796 ${ }^{F}$

\section{Conflict of interest:}

The Authors declare no conflict of interest.

\section{CORRESPONDING AUTHOR}

\section{Serhii M. Korol}

Sumy State University

2 Rimsky-Korsakov St., 40000 Sumy, Ukraine

tel: +380730682771

e-mail:physical_education_2020@ukr.net

Received: 09.11 .2020
Accepted: 20.04 .2021

A - Work concept and design, B - Data collection and analysis, C - Responsibility for statistical analysis, D-Writing the article, $\mathbf{E}$-Critical review, $\mathbf{F}-$ Final approval of the article 